\title{
REGONNAISSANGE OF A SMALL IGE CAP NEAR ST PATRICK BAY, ROBESON CHANNEL, NORTHERN ELLESMERE ISLAND, CANADA
}

\author{
By G. Hattersley-Smith and H. Serson \\ (Defence Research Establishment Ottawa, Ottawa, Ontario $\mathrm{K}_{\mathrm{IA} \mathrm{OZ}}$, Canada)
}

\begin{abstract}
A reconnaissance was made of one of two small ice caps near the Robeson Channel coast of northern Ellesmere Island. It is shown that, after a period of net wastage, this ice cap is now thickening slightly and extending its margins. The present regime of the ice cap is a direct result of generally cooler summers in the last decade.

Résumé. Exploration d'une petite calotte glaciaire près de St Patrick Bay, dètroit de Robeson, nord de l'île Ellesmere, Canada. Une exploration effectuée près des côtes du détroit Robeson d'une des deux petites calottes glaciaires de l'île Ellesmere nord a montré qu'après une période de nette ablation la calotte s'épaissit légèrement et étend ses bords. Le régime présent de la calotte glaciaire résulte directement des températures estivales plus froides rencontrées pendant la dernière décennie.

Zusammenfassung. Erkundung eines kleinen Eisschildes nahe der St Patrick-Bay, Robeson-Channel, Nord-EllesmereIsland, Kanada. Eine Erkundung galt einem der beiden kleinen Eisschilde nahe der Robeson-Channel-Küste auf der nördlichen Ellesmere-Island. Es wird gezeigt, dass dieser Eisschild nach einer Periode des NettoMassenverlustes jetzt allmählich an Dicke zunimmt und seine Ränder ausdehnt. Das gegenwärtige Verhalten des Eisschildes ist eine direkte Folge der im allgemeinen kühleren Sommer während des letzten Jahrzehnts.
\end{abstract}

\section{INTRODUCTION}

In the rolling plateau area that stretches south-westward from Alert towards Lake Hazen and is bounded by the south-eastern margin of the Grant Ice Cap, hill-top altitudes nowhere exceed $900 \mathrm{~m}$ while the average altitude is about $600 \mathrm{~m}$ (Fig. $\mathrm{I}$ ). With one exception none of the hills is permanently ice-covered. The exception is a broad saddleback about $15 \mathrm{~km}$ due north of St Patrick Bay on the Robeson Channel coast. This hill carries two small ice caps, of which the larger (north-eastern) has an area of about $7.3 \mathrm{~km}^{2}$, the smaller (southwestern) an area of about $2.6 \mathrm{~km}^{2}$. The highest point on this hill, a little to the west of the southern ice cap, is shown as $2760 \mathrm{ft}(84 \mathrm{I} \mathrm{m})$, and the summit level of the ice is probably about $830 \mathrm{~m}$. The ice caps are drained by small streams running northward and southward from the divide. They represent the most easterly development of permanent ice in the Queen Elizabeth Islands, and it can be assumed that the elevation of $830 \mathrm{~m}$ is close to the glaciation limit in the immediate area. Evidently the glaciation limit is somewhere lower here than the $>900 \mathrm{~m}$ altitude in the plateau area to the north-west.

Small ice caps of this type are very sensitive to short-term climatic changes, particularly to temperature fluctuations in the ablation season. From data obtained in 1964 on a small ice cap near Tanquary Camp, it was suggested that a $\mathrm{I}$ to 2 deg decrease in mean temperature continued over a number of years could lead to a wide extension of ice margins in the Tanquary Fiord area (Hattersley-Smith, I969, p. 48-49). More recently Bradley and Miller (I972) correlated the increase in size of existing snow banks and the generation of new permanent snow banks in northern Cumberland Peninsula (Baffin Island) with lower summer temperatures in the last decade. They also pointed out that for the plateau region north of the Barnes Ice Cap (northern Baffin Island) - an area that was much more extensively ice-covered within the last 400 years (Ives, I962) - a mean summer cooling of only I.5 deg, augmented by increased snowfall, would be sufficient to cause a marked increase in the number and size of thin ice caps.

From an air photograph taken on 6 July I959 (Fig. 2) we see that the entire ice caps north of St Patrick Bay were in the ablation zone as shown by the surface dirt layer and the complete exposure of stratigraphic layering and surface drainage patterns. In the case of the larger ice cap the surface drainage is seen to radiate from the domes to the east and west, and 


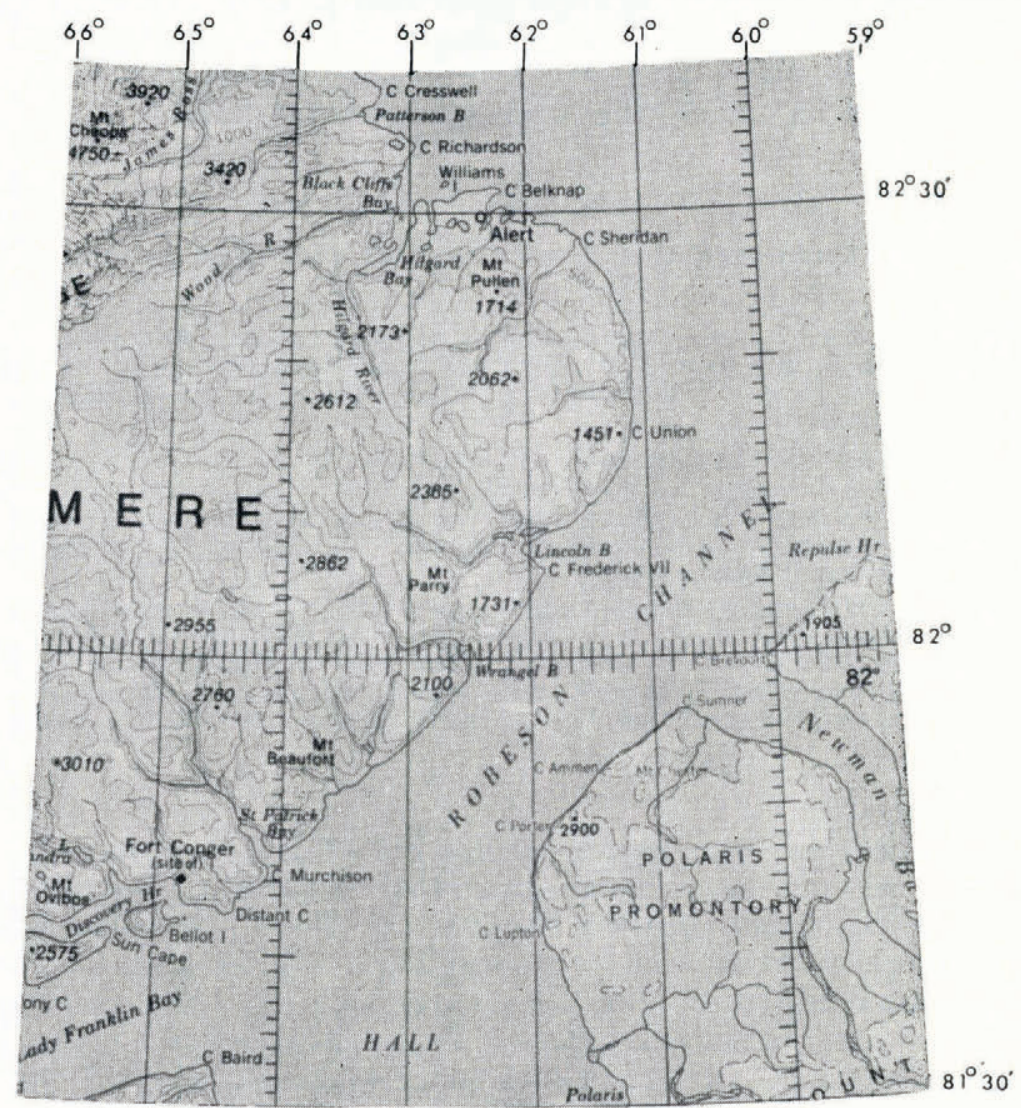

Fig. 1. Robeson Channel coast of north-eastern Ellesmere Island, showing two small ice caps north of St Patrick Bay (part of NTS Sheet No. 120, 1968).

to converge towards the narrow valleys on the north and south sides. The upper parts of both these valleys are more or less filled with snowdrift ice; the steep dirt-covered ice cliff of the northern valley should be noted in Figure 2. The only other available air photograph, an oblique taken on 24 June I950, shows the ice caps under a complete cover of snow.

It was thought that these small ice caps, like those elsewhere, might reflect a recent climatic cooling. If so, in late summer the heavy dirt layer would not now be exposed but would be covered by surface accumulation.

\section{OBSERVATIONS}

The larger of the two ice caps was visited by H. Serson and J. A. Morrison on 28 July 1972. They landed by helicopter near the margin of the ice cap and during the course of a day set up a line of eight poles across about two-thirds of its width. The work was carried out in very poor visibility in fog, and this resulted in the eastern margin of the ice cap not being reached. However, it was evident that the entire ice cap was covered by snow pack of the $1971-72$ winter to a maximum depth of $38 \mathrm{~cm}$. Partial melting and refreezing within the snow pack had of course occurred, but it seemed unlikely that much more melting would take place during the summer. 


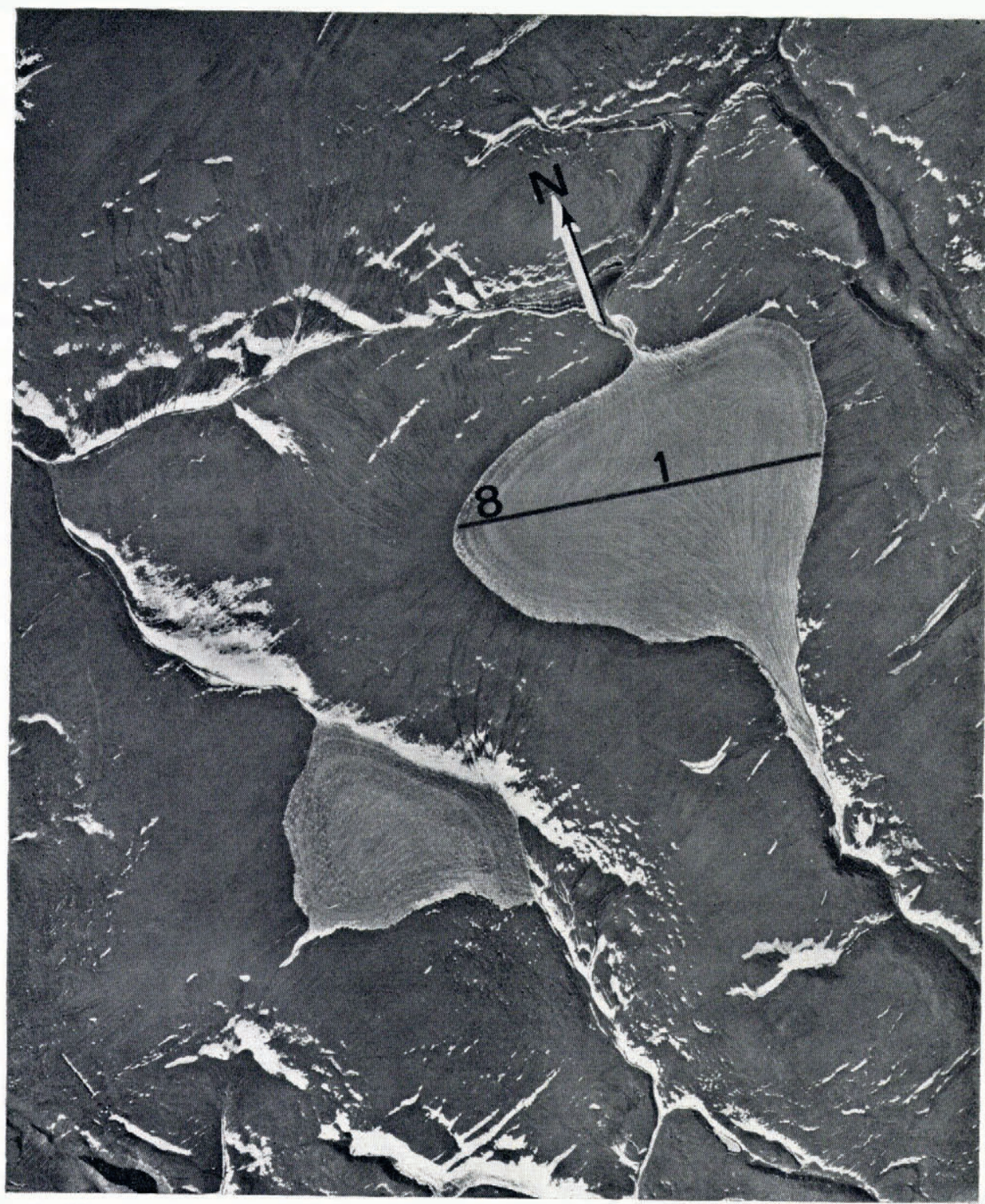

Fig. 2. Small ice caps north of St Patrick Bay at approximate scale $I: 80$ ooo, 6 July 1959. (Photograph by Department of Energy, Mines and Resources: A I6603-1.5.)

A second visit was made to the ice cap by G. Hattersley-Smith and A. Davidson from 20 to 2 I August. They landed by helicopter on the dome on the west side in good weather with excellent visibility. Apart from the complete snow cover on the ice cap, the situation at the margins was very different from that shown in Figure 2, where a clear-cut ice edge against bare ground showed in the 1959 summer. Now there was a partial cover of winter snow all around the ice margin for at least a kilometre, and to determine the extent of the ice it was necessary to dig down through the snow to find rocks. It was clear that the ice margin is encroaching on previously ice-free ground, for irregular patches of ice and unmelted I $97 \mathrm{I}-72$ 
snow covered the rocks. From $300 \mathrm{~m}$ beyond the average position of the western ice margin, an altimeter and chain traverse was carried across the ice cap to the eastern margin, following the line of poles I to 8 set up by Serson and Morrison (Fig. 2). The results of this traverse are shown in Figure 3, but the altimetry, particularly on the eastern side, cannot be considered accurate to better than $\pm 2 \mathrm{~m}$, and the accuracy may be less than that. At each pole, heights from top of pole to snow surface were scaled off and pits were dug to determine the $197 \mathrm{I}-72$ snow stratigraphy. These results are also shown in Figure 3, together with estimates of the snow accumulation in $\mathrm{cm}$ (water equivalent) based on estimated densities for different layers in the snow pack, since no densities were measured in the field. A 3 in $(7.6 \mathrm{~cm})$ CRREL coring auger was used to extract cores of firn and ice from beneath the snow pack, and to determine the depth of the heavy dirt layer. The dirt layer was found at each pole and at one other coring site on the eastern part of the ice cap; it was also found near the margins of the ice cap. The dirt layer was invariably associated with cryoconite holes in the ice to an average depth of $5 \mathrm{~cm}$.

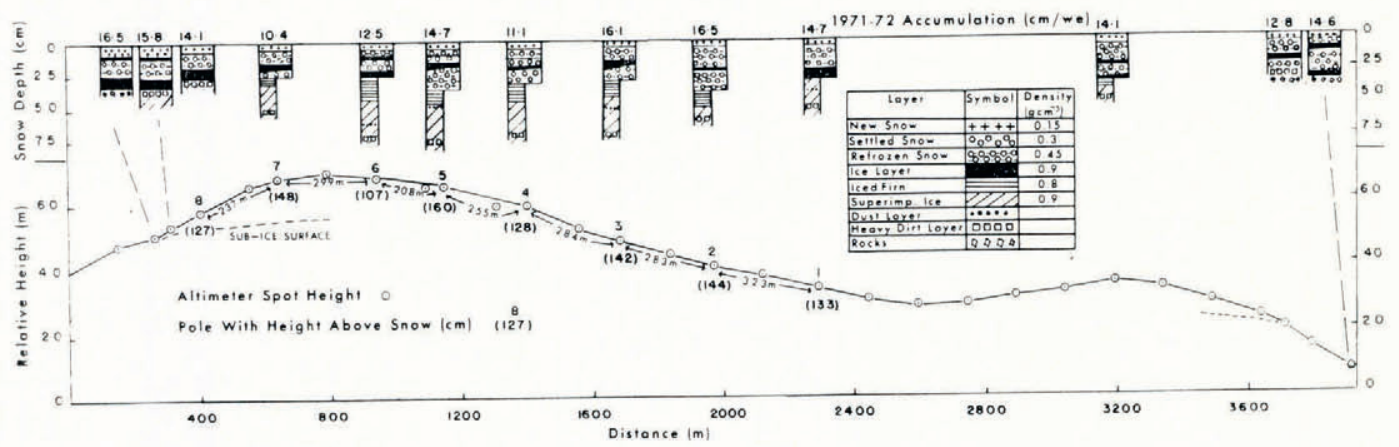

Fig. 3. Snow and ice stratigraphy along north-west-south-east profile of larger ice cap, 20-2I August I972.

\section{Discussion}

The measurements in 13 snow pits and the cores taken from the bottom of the snow pits allow not only estimates of the net accumulation for the $197 \mathrm{I}-72$ budget year (assuming that no significant loss occurred from the ice cap after 2I August), but also an assessment of the regime represented by accumulation above the heavy dirt layer that is so evident in the I959 air photograph (Fig. 2). The mean net accumulation for $197 \mathrm{I}-72$ was approximately I4 $\mathrm{cm}$ water equivalent. This figure is comparable with the annual precipitation measured at Alert which varies from io to $20 \mathrm{~cm}$ water equivalent. The $1972-72$ snow pack rested on very icy firn beneath which there was superimposed ice. The maximum depth of the cryconite dirt layer beneath the bottom of the snow pack was $48 \mathrm{~cm}$. Allowing $5 \mathrm{~cm}$ for the depth of the cryconite holes, this means an accumulation of up to $43 \mathrm{~cm}$ of iced firn and superimposed ice, or about $39 \mathrm{~cm}$ water equivalent above the old ablation surface. Accumulation was greatest near the western dome of the ice cap and fell off to the east and west. Near the eastern margin the dirt layer appeared to rest on the rocks.

The recent history of the ice cap is seen as follows. It underwent a period of net ablation at least until the year r 959. This caused the concentration of successive seasons wind-blown dust and the development of a cryoconite surface. It is likely that this period of net ablation continued at least until 1962 which from data elsewhere in northern Ellesmere Island was an exceptionally warm summer. Subsequently there has been a period of net build-up first of superimposed ice, and, most recently, of iced firn, perhaps broken by one or more seasons of net ablation represented by a distinct dust layer near the top of the ice (Fig. 3). 
From topographic considerations (Fig. 3) it can be seen that the probable thickness of the ice cap is from 15 to a maximum of $20 \mathrm{~m}$. It was probably wasting rather rapidly in the period prior to 1959, since it lay so close to the glaciation limit. It now appears to be in a healthy state and is spreading laterally as well as thickening. From its location due north of Hall Basin, it is more favourably situated to receive precipitation from southerly winds than are other hilltops to the west. In this way its nourishment is doubtless influenced by open water conditions in the Nares Strait.

\section{Conclusion}

As a climatic indicator it will be well worth keeping a check on the regime of this ice cap, and to arrange for rephotographing under conditions of minimum snow cover. If the trend to cooler summers continues, extension of snow banks and development of thin ice caps may be expected in the general region south-west of Alert.

MS. received 12 February 1973

\section{REFERENCES}

Bradley, R. S., and Miller, G. H. 1972. Recent climatic change and increased glacierization in the eastern Canadian Arctic. Nature, Vol. 237, No. 5355, p. $385-87$.

Hattersley-Smith, G. I 969 . Glacial features of Tanquary Fiord and adjoining areas of northern Ellesmere Island, N.W.T. Journal of Glaciology, Vol. 8, No. 52, p. 23-50.

Ives, J. D. 1962 . Indications of recent extensive glacierization in north-central Baffin Island, N.W.T. Journal of Glaciology, Vol. 4, No. 32, p. 197-205. 